\title{
Pembangunan Hukum Sebagai Upaya Peningkatan Daya Saing Daerah
}

\section{Dewi Ayu Rahayu.}

Dewi Ayu Rahayu; Fakultas Hukum Universitas Merdeka Malang; Jl. Terusan Dieng No. 62 - 64; Malang; 65115; Jawa Timur; Indonesia.

\begin{tabular}{l}
\hline A R T I C L E I N F O \\
\hline Article history: \\
Received 2019-03-23 \\
Received in revised form \\
2019-05-27 \\
Accepted 2019-07-01 \\
\hline
\end{tabular}

Kata kunci:

Pembangunan Hukum, Peran Hukum, Daya Saing Daerah.

Keywords:

Legal Development, Role of Law, Regional Competitiveness.

\section{Citation:}

Rahayu, D. (2019). Pembangunan Hukum Sebagai Upaya Peningkatan DayaSaing Daerah.Jurnal Cakrawala Hukum, 10(1). doi:10.26905/idjch.v10i1.3181
Pelaksanaannya, pembangunan bukan entitas yang berdiri sendiri, melainkan terintegrasi dan menjadi satu kesatuan dengan komponen-komponen pembangunan yang ada. Tujuan penelitian ini untuk mengkaji konsep hukum melalui pembangunan hukum sebagai upaya mewujudkan daya saing daerah. Jenis penelitian yang akan digunakan adalah Penelitian Yuridis-Normatif. Penelitian ini dilakukan dengan metode Yuridis-Normatifdikarenakan dalam penelitian ini menggunakan pendekatan undangundang Hasil dari penelitian ini menunjukkan bahwa daya saing daerah berkorelasi dengan pembangunan hukum nasional sebagaimana yang terncantum dalam Undangundang Nomor 17 tahun 2007 tentang Rencana Pembangunan Jangka Panjang Nasional yang sebelumnya tercantum dalam Garis-garis Besar Haluan Negara. Teori hukum pembangunan generasi kedua melalui konsep hukum tidak hanya sebagai sarana pembangunan, tetapi juga sebagai sarana pembaharuan birokrasi. Pembangunan hukum yang akan meningkatkan daya saing bangsa perlu memperhatikan tiga hal penting, pertama, pembangunan peraturan perundangundangan yang berkualitas dan bermanfaat. Mewujudkan daya saing setiap daerah di Indonesia yang tentunya akan berdampak pada kesejahteraan Negara tentu harus diiringi oleh pembangunan hukum baik secara substansi hukum, struktur hukum dan budaya hukum.

\section{Abstract}

Implementation, development is not a stand-alone entity, but rather integrated and becomes a unit with existing development components. The purpose of this study is to examine legal concepts through legal development as an effort to realize regional competitiveness. The type of research that will be used is Juridical-Normative Researchers. This research in conjunction with the juridical-normative method in this study uses the results of this study to show that regional competitiveness correlates with the development of national law as stated in Law Number 17 of 2007 concerning the National LongTerm Development Plan that was previously listed in the Outlines of State Policy. The second generation legal theory of development through legal concepts is not only a means of development, but also as a means of renewing the bureaucracy. The development of laws that will improve the competitiveness of the nation needs to pay attention to three important things, first, the development of quality and beneficial legislation. Realizing the competitiveness of each region in Indonesia, which of course will have an impact on the welfare of the State, of course, must be accompanied by legal development both in the substance of the law, legal structure and legal culture.

Corresponding Author:

Dewi Ayu Rahayu

E-mail address: dewi.rahayu@unmer.ac.id

DOI: https://doi.org/10.26905/idjch.v10i1.3181. 


\section{Jurnal Cakrawala Hukum, Volume 10 No. 1 Juni 2019}

ISSN PRINT 2356-4962 ISSN ONLINE 2598-6538

\section{Latar Belakang}

Hakikatnya, pembangunan adalah upaya sistematis dan terencana oleh masing-masing atau seluruh komponen bangsa untuk mengubah suatu keadaan yang bertujuan untuk meningkatkan kualitas hidup manusia. Pelaksanaannya, pembangunan bukan entitas yang berdiri sendiri, melainkan terintegrasi dan menjadi satu kesatuan dengan komponen-komponen pembangunan yang ada. Salah satu komponen yang berperan dalam pelaksanaan pembangunan adalah komponen hukum. Hukum harus ditempatkan sebagai panglima dalam segala hal, setiap tindakan atau perbuatan pemerintah harus dilaksanakan berdasar kewenangan yang telah diatur dalam peraturan perundangundangan, hal ini sebagai konsekuensi dari Indonesia sebagai Negara hukum, sebagaimana yang diamanatkan dalam konstitusi.

Pembangunan dalam arti seluas-luasnya memiliki makna adanya suatu upaya untuk mentransformasikan masyarakat dari suatu kondisi ke kondisi yang lebih baik dan meliputi segala kehidupan masyarakat yang tidak hanya dari segi kehidupan ekonomi belaka, dalam hal ini kemudian menimbulkan suatu persoalan yakni adakah peranan dalam hukum dalam proses pembangunan itu; dan apabila hukum beperan dalam pembangunan tersebut maka apakah peranannya?

Peranan hukum sebagai sarana pembangunan telah tercantum dalam Repelita II Bab 27 yang mana konsepsi hukum tersebut merupakan salah satu sarana pembaharuan dan pembangunan masyarakat dengan memuat pokok-pokok kebijaksanaan serta garis besar program pembinaan hukum nasional sebagai penjabaran (uitwerking) daripada konsepsi hukum tersebut. Bahwa peran hukum dalam pembangunan adalah untuk menjamin perubahan itu terjadi dengan cara yang teratur.

Peranan hukum sebagai sarana pembangunan telah ditegaskan pula oleh Kepala Negara RI pada waktu pelantikan Menteri Kehakiman pada tanggal 19 Januari 1974. Pada kesempatan tersebut dinyatakan antara lain bahwa: "walaupun pembangunan mengharuskan rangkaian perubahan yang mendesak, akan tetapi sangat mutlak pula terpeliharanya ketertiban itu sendiri tidak boleh diberi arti yang statis, yang hanya mempertahankan "status quo". Hukum sebagai sarana yang penting untuk memelihara ketertiban harus dikembangkan dan dibina sedemikian, sehingga dapat memberi ruang gerak bagi perubahan tadi. Bukannya sebaliknya, menghambat usaha-usaha pembaharuan karena semata-mata ingin mempertahankan nilai-nilai lama. Sesungguhnya hukum harus dapat tampil ke depan, menunjukkan arah dan memberi jalan bagi pembaharuan". (Kusumaatmadja, 1976)

Sebagaimana fungsi hukum yang utama yakni sebagai 'a tool of social engineering' atau rekayasa sosial yang diharapkan dapat membawa perubahan mendasar sikap masyarakat serta berperan aktif dalam setiap pembangunan nasional.

Namun seiring dengan perkembangan kebijakan pembangunan nasional terjadi perubahan orientasi dalam pengelolaan pembangunan. Pada masa orde baru pembangunan lebih berorientasi pembangunan ekonomi yang bertujuan menciptakan pertumbuhan ekonomi yang tinggi yang oleh karenanya hukum ditempatkan sebagai instrumental untuk memfasilitasi pembangunan, bukan dalam pengertian hukum sebagai law is a tool of social engineering (Mahfud, 1999) di mana perencanaan pembangunan selalu dituangkan dalam bentuk GBHN maupun Repelita. Akan tetapi pasca reformasi terutama setelah terjadi amandemen Undang-Undang Dasar Negara Republik Indonesia Tahun 1945 (selanjutnya ditulis dengan UUD 1945) yang keempat kalinya terjadi perubahan pengelolaan pembangunan yang antara lain adalah pertama, penguatan kedudukan lembaga legislatif dalam penyusunan APBN, kedua, ditiadakannya GBHN sebagai pedoman penyusunan rencana pembangunan nasional, ketiga, diperkuatnya Otonomi Daerah dan disentralisasi 
pemerintahan dalam Negara Kesatuan Republik Indonesia.

GBHN sebagai arah pembangunan nasional, Indonesia tetap memerlukan adanya rencana pembangunan jangka panjang sebagai arah dan prioritas pembangunan secara menyeluruh yang akan dilakukan secara bertahap untuk mewujudkan masyarakat yang adil dan makmur. Tercapainya hal tersebut sebagaimana amanat dalam Pasal 13 ayat (1) Undang-Undang Nomor 25 Tahun 2004 tentang Sistem Perencanaan Pembangunan Nasional agar Rencana Pembangunan Jangka Panjang Nasional Lembaran Negara Republik Indonesia Tahun 2004 Nomor 104, Tambahan Lembaran Negara Republik Indonesia Nomor 4421 bahwa system perencanaan pembangunan nasional ditetapkan melalui Undang-Undang, yang kemudian lahirlah Undang-Undang Nomor 17 Tahun 2007 tentang Rencana Pembangunan Jangka Panjang Nasional Tahun 2005-2025 Lembaran Negara Republik Indonesia Tahun 2007 Nomor 33, Tambahan Lembaran Negara Republik Indonesia Nomor 4700 (selanjutnya ditulis dengan UU RPJP Nasional).

Merujuk pada lampiran UU RPJP Nasional dalam arah pembangunan jangka panjang tahun 2005-2025 salah satu poin nya adalah mewujudkan bangsa yang berdaya saing dengan mengedepankan pembangunan sumber daya manusia berkualitas dan berdaya saing, memperkuat perekonomian domestik berbasis keunggulan di setiap wilayah menuju keunggulan kompetitif dengan membangun keterkaitan sistem produksi, distribusi, dan pelayanan di dalam negeri. Pada dasarnya daya saing juga merupakaan salah satu dari tujuan pembangunan nasional sebagaimana tercantum dalam UU RPJP Nasional. Begitupun dengan daerah-daerah yang ada di Indonesia yang memiliki daya saing berbeda diantara daerah satu dengan lainnya sehingga antar daerah memiliki suatu keunggulan yang berbeda yang terdiri dari faktor keunggulan komparatif dan faktor keungggulan kompetitif.
Dengan adanya daya saing antar daerah di Indonesia dapat meningkatkan dan mewujudkan pembangunan nasional dengan tujuan Negara sebagaimana yang tercantum dalam Pembukaan UUD 1945. Dengan terwujudnya pembangunan nasional maka akan berkorelasi pada pembangunan hukum di Indonesia.

\section{Metode}

Jenis penelitian yang akan digunakan adalah Penelitian Yuridis-Normatif. Penelitian ini dilakukan dengan metode Yuridis-Normatif dikarenakan dalam penelitian ini menggunakan pendekatan undang-undang (Statuta Approach) menelaah undang-undang dan regulasi yang bersangkut paut dengan penelitian (Marzuki, 2005) dalam hal ini merujuk pada Undang-undang Rencana Jangka Panjang Nasional.

\section{Pembahasan}

3.1. Korelasi Pembangunan Hukum dengan Daya Saing Daerah

Daya saing sebuah daerah adalah kumpulan dari institusi institusi daerah, kebijakan-kebijakan dan faktor-faktor lain yang menentukan produktifitas suatu daerah. Tingkat produktifitas suatu daerah menentukan tingkat kesejahteraan ekonomi daerah tersebut dan akan berdampak pula pada kesejahteraan Negara.

Di Indonesia sendiri pengukuran daya saing dilakukan dengan menggunakan kerangka piramida, yang teridiri dari interaksi antara factor input-output-outcome. Hasil pemetaan tersebut telah menghasilkan posisi dan peringkat daya saing masing-masing Kabupaten/Kota (Soebagyo, 2013).

Hasil pemetaan daya saing daerah secara keseluruhan menunjukkan bahwa daerah yang memiliki daya saing tinggi secara umum didominasi oleh Kabupaten/Kota yang memiliki basis ekonomi bersumber pada kekayaan sumber daya alam dan/ atau daerah-daerah yang memiliki aktivitas eko- 
nomi berbasis sektor industri dan sektor jasa. Sedangkan daerah Kabupaten/Kota yang memiliki daya saing daerah terendah, umumnya daerah dengan basis ekonomi sektor primer, khususnya pertanian (PPSK-Bank Indonesia dan LP3E Unpad, 2008)

Meningkatkan daya saing masing-masing daerah diperlukan adanya kebijakan suatu negara yang akan mempengaruhi tingkat produktifitas daya saing daerah. Konsep daya saing berkaitan dengan aktivitas perekonomian dan hal itupun biasanya dipahami dalam kerangka pikrr ekonomi. Konsep ini pada dasarnya menjelaskan upaya peningkatan bargaining position dalam rangka memaksimalkan pencapaian tujuan kita berhadapan dengan posisi dan tujuan pihak lain.

Peranan negara dalam konteks peningkatan daya saing merupakan hal yang urgent. Peran Negara dalam hal ini pemerintah pada peningkatan daya saing sangat menentukan karena pemerintah yang berwenang untuk mengeluarkan kebijakan, hukum, dan membangun infrastruktur, sekolah dan rumah sakit yang akan mendukung tingginya daya saing.

Aspek hukum dalam peningkatan daya saing adalah, Pertama, kewenangan untuk membuat hukum atau regulasi dan juga menegakkannya dimiliki oleh pemerintah. Kewenangan ini sangat menentukan kebijakan ekonomi makro yang diambil oleh sebuah negara. Karena pada umumnya daya saing dikaitkan dengan konsep comparative advantage, yakni dimilikinya unsur-unsur penunjang proses produksi yang memungkinkan satu negara menarik investor untuk melakukan investasi ke negaranya, tidak ke negara yang lain. Konotasi advantage di sini adalah situasi yang memungkinkan pemodal menuai keuntungan semaksimal mungkin. Kedua, kebijakan hukum pemerintah sangat menentukan dalam mendorong pilar-pilar daya saing yang lain untuk maju. Kebijakan pemerintah yang berorientasi untuk mendorong infrastruktur, pelayanan publik, pendi- dikan, kesehatan, dan insentif lainnya sangat menentukan daya saing suatu daerah. Sebagaimana tugas pemerintah jika ditinjau menggunakan teori analysis economic of law, bahwa Pemerintah harus meningkatkan efisiensi dalam segala bidang, menciptakan pemerataan dan keadilan serta memacu pertumbuhan ekonomi secara makro dan memelihara stabilitasnya.

Pergeseran paradigma daya saing telah lama berlangsung dari teori klasik ke teori model Michael Porter. Model baru, daya saing tidak hanya berintikan peran pelaku usaha, akan tetapi juga pemerintah melalui kebijakan, kelembagaan dan pelayanan publik yang dihasilkan. Pemerintah memiliki peran penting dalam mendukung perkembangan industri dan kegiatan ekonomi secara umum melalui penerbitan regulasi dan instrument fiskal (Prawira, 2018). Oleh karena itu kehadiran negara dalam aktivitas ekonomi menjadi penting. J.D. Hart berpendapat bahwa kehadiran negara dalam membangun ekonomi dilakukan melalu instrumen hukum dengan tujuan agar hukum dapat menciptakan kondisi stabilitas (stability), memprediksi kondisi perekonomian di masa yang akan datang (predictability) dan menciptakan keadilan (fairness) dalam melakukan aktivitas ekonomi. Sebagai stabilisator hukum mampu menyeimbangkan dan mengakomodasi kepentingankepentingan yang saling bersaing dalam aktivitas ekonomi.

Fungsi hukum yang predictability adalah bahwa hukum dapat memprediksi akibat dari suatu langkah-langkah yang diambil, khususnya negara-negara berkembang yang memasuki era globalisasi dan perdagangan bebas predikbilitas merupakan suatu hal yang urgen. Dalam konteks keadilan (fairness) bahwa hukum harus mampu menciptakan suatu perlakuan yang sama terhadap semua pelaku usaha dalam melakukan aktivitas ekonomi dan juga untuk menciptakan pola tingkah laku pemerintah untuk menjaga mekanisme pasar dan birokrasi yang berlebihan. 
Konteks peranan hukum dalam membangun daya saing bangsa maka hukum harus ditempatkan sebagai "pendulum" pembangunan nasional. Hukumlah yang kemudian mengarahkan pembangunan ekonomi dan infrastruktur dan bidang pembangunan yang lain. Hukum sebagai dasar dari pembangunan nasional maka sangat diperlukan sebagai pelindung untuk menghindari dan mengurangi terjadinya konflik. Pembangunan nasional dengan arah kebijakan mewujudkan bangsa yang berdaya saing, begitupula pada setiap daerah yang ada di Indonesia yang mana masingmasing daerah memiliki RPJP Daerah nya sendiri dengan arah kebijaka nya juga mewujudkan daerah yang dapat berdaya saing.

Misal dalam program pembangunan daerah Kota Malang sebagaimana yang tercantum dalam Peraturan Daerah Kota Malang Nomor 5 Tahun 2010 tentang Rencana Pembangunan Jangka Panjang Daerah Tahun 2005-2025 Lembaran Daerah Kota Malang Tahun 2010 Nomor 3 Seri E dalam Pasal 2 disebutkan bahwa RPJP Daerah merupakan penjabaran dari tujuan otonomi daerah yaitu untuk meningkatkan kesejahteraan masyarakat, meningkatkan pelayanan umum dan meningkatkan daya saing daerah. Begitupula dalam Peraturan Daerah Kota Pontianak Nomor Tahun 2014 tentang Rencana Pembangunan Jangka Menengah Daerah Kota Pontianak Tahun 2015-2019 bahwa program Pemerintah dalam RPJM Daerah Kota Pontianak adalah mewujdukan Kota Pontianak yang memliki aspek daya saing.

Dengan adanya aspek daya saing pada setiap program dalam RPJP Daerah ataupun RPJM Daerah maka akan berimbas pada peningkatan kesejahteraan masyarakat pada daerah masing-masing. Oleh karena itu setiap masing-masing daerah harus memiliki keunggulan atau kearifan lokal untuk meningkatkan daya saing setiap daerah.

Agar arah kebijakan daya saing setiap daerah dapat dilaksanakan dengan adil dan tanpa adanya konflik antar daerah maka diperlukan hukum sebagai pelindung sekaligus dasar kebijakan pada daerah tersbut. Tetapi dalam hal ini hukum tidak hanya sebagai instrument untuk meningkatkan daya saing, tapi hukum harus ditempatkan sebagai rekayasa sosial atau law as a tool of social engineering.

3.2. Konsep Pembangunan Hukum Sebagai Upaya Mewujudkan Daya Saing Daerah

Pembangunan nasional adalah rangkaian upaya pembangunan yang berkesinambungan yang meliputi seluruh aspek kehidupan masyarakat, bangsa dan negara, untuk melaksanakan tugas mewujudkan tujuan nasional sebagaimana dirumuskan dalam Pembukaan UUD 1945. Rangkaian upaya pembangunan tersebut memuat kegiatan pembangunan yang berlangsung tanpa henti, dengan menaikkan tingkat kesejahteraan masyarakat dari generasi demi generasi. Pelaksanaan upaya tersebut dilakukan dalam konteks memenuhi kebutuhan masa sekarang tanpa mengurangi kemampuan generasi yang akan datang untuk memenuhi kebutuhannya.

Pelaksanaan pembangunan tersebut merupakan upaya untuk mencapai tujuan Negara sebagaimana yang tercakup dalam alinea keempat UUD 1945, yaitu melindungi segenap bangsa dan seluruh tumpah darah Indonesia, memajukan kesejahteraan umum, mencerdaskan kehidupan bangsa dan ikut melaksanakan ketertiban dunia, berdasarkan kemerdekaan, perdamaian abadi dan keadilan sosial. (Setiadi, 2012)

Prinsinsipnya, kerangka utama strategi politik mengenai pembangunan hukum nasional itu selama tiga dasawarsa yang lalu mempunyai konsep dasar yang sama yakni melalui UUD 1945, yang kemudian dimuat secara jelas dalam GBHN sebelum diubah dan diatur dalam UU RPJP Nasional.

Pembangunan Jangka Panjang Nasional Tahun 2005-2025 merupakan kelanjutan dari pembangunan sebelumnya untuk mencapai tujuan pembangunan sebagaimana diamanatkan dalam Pembukaan UUD 1945. 20 tahun mendatang, sangat 
penting dan mendesak bagi bangsa Indonesia untuk melakukan penataan kembali berbagai langkah-langkah, antara lain di bidang pengelolaan sumber daya alam, sumber daya manusia, lingkungan hidup dan kelembagaannya sehingga bangsa Indonesia dapat mengejar ketertinggalan dan mempunyai posisi yang sejajar serta daya saing yang kuat di dalam pergaulan masyarakat Internasional.

Pembangunan hukum berdasarkan UU RPJP Nasional sebagaimana yang tercantum dalam lampiran UU RPJP Nasional pembangunan hukum dibagi menjadi tiga hal yakni, Pertama, pembangunan substansi hukum, baik hukum tertulis maupun hukum tidak tertulis telah mempunyai mekanisme untuk membentuk hukum nasional yang lebih baik sesuai dengan kebutuhan pembangunan dan aspirasi masyarakat, yaitu berdasarkan Undang-Undang Nomor 10 Tahun 2004 tentang Pembentukan Peraturan Perundang-undangan.

Melihat pembangunan hukum nasional dalam lampiran Undang-Undang RPJP Nasional dapat diketahui bahwa keinginan dari pembuat Undang-Undang dalam hal ini penguasa menghendaki adanya perubahan dan/atau pembentukan suatu Undang-Undang yang sesuai dengan aspirasi masyarakat sebagaimana yang dikemukakan oleh Eugen Ehrlich dengan konsep "living law" bahwa hukum yang baik adalah yang mencerminkan nilai-nilai yang hidup dalam masyarakat, hal ini senada dengan pendapat Von Savigny dengan konsep "Volkgeist".

Arah pembangunan hukum nasional berdasarkan UU RPJP Nasional dalam Rencana Kerja Pemerintah tahun 2018 dalam Sembilan Program Prioritas Nawacita lebih ditekankan pada reformasi system dan penegakan hukum yang bebas korupsi bermartabat dan terpercaya karena dalam program pembangunan nasional prioritas pemerintah menitikberatkan pada pembangunan infrastruktur dan ekonomi yang diperkuat oleh arah kebijakan pembangunan hukum dalam RKP 2018 fokus Pemerintah hanya pada penegakan hukum yang berkualitas, pencegahan dan pemberantasan korupsi yang efektif; dan penghormatan, perlindungan dan pemenuhan hak atas keadilan.

Dengan hal itu maka fokus pembangunan hukum pemerintah bukan pada perubahan hukum atau pembentukan hukum yang sesuai dengan aspirasi masyarakat tetapi menitikberatkan pada penegakkan hukum. Jika dikaji berdasarkan system hukum menurut Lawrence Friedman yang terdiri dari substansi hukum, struktur hukum dan budaya hukum maka pemerintah lebih cenderung pada struktur hukum dalam hal ini adalah penegakkan hukum.

Arah pembangunan hukum yang menggunakan teori pembangunan hukum Mochtar Kusumaatmadja maupun teori sistem hukum dari Lawrence W Friedmen perlu direkonseptualisasi keaktualisasian dan ketepatannya berdasarkan pada kondisi Indonesia saat ini. Teori hukum pembangunan generasi kedua seperti yang disampaikan Romli Atmasasmita melalui konsep hukum tidak hanya sebagai sarana pembangunan, tetapi juga sebagai sarana pembaharuan birokrasi. Begitu juga dengan teori hukum progresif yang dikemukakan Satjipto Rahardjo. Landasan ilmiah pembangunan hukum nasional kemudian dapat berkesesuaian dengan kondisi hukum Indonesia.

Kedua, implementasi arah pembangunan hukum dalam RPJMN. Hal yang tidak kalah pentingnya dalam reformasi pembangunan hukum nasional adalah mengimplemantasikan arah pembangunan hukum dalam RPJP menjadi RPJMN, RKP, dan Program pembangunan hukum. untuk menjamin bahwa visi Indonesia tahun 2025 menjadi negara sejartera, maju dan mandiri harus dapat diwujudkan melalaui RPJMN, RKP dan program yang dilakukan oleh Presiden terpilih. Program Nawacita oleh Presiden dalam pembangunan hukum harus tercermin dalam program-program pembangunan hukum.

Mewujudkan dua konsep di atas, ketika hukum ditempatkan untuk membangun daya saing 
bangsa hukum ditempatkan sebagai pendorong pembangunan maka komponen komponen sistem hukum yang dikemukakan Lawrence M Friedman harus dilakukan reformasi pembangunan hukum. Pembangunan hukum yang akan meningkatkan daya saing bangsa perlu memperhatikan tiga hal penting, pertama, pembangunan peraturan perundangundangan yang berkualitas dan bermanfaat.

Meningkatkan daya saing bangsa maka pemerintah dan DPR harus melakukan evaluasi peraturan perundang-undangan pada tingkat sinkronisasi dan harmonisasi. Harmonisasi peraturan perundang-undangan yang bersifat vertikal dengan UUD 1945 dan perjanjian internasional yang telah diratifikasi Indonesia. Peraturan perundang-undangan yang penting juga dilakukan adalah sinkronisasi dan harmonisasi Peraturan daerah (perda) dengan peraturan perundang-undangan di atasnya. Harmonisasi horizontal dilakukan dengan melakukan penyesuian dengan peraturan perundang-undangan yang sama kedudukan hierarkinya.

Kedua, yang perlu diperbaiki dalam konteks pembangunan hukum untuk meningkatkan daya saing adalah pembangunan struktur hukum. Ketiga, yang perlu diperbaiki adalah budaya hukum masyarakat. Dalam konteks kegiatan ekonomi praktek suap-menyuap antara pelaku usaha dengan pejabat pemerintahan khususnya dalam pengurusan adalah budaya hukum yang harus diperbaiki.

Mewujudkan daya saing setiap daerah di Indonesia yang tentunya akan berdampak pada kesejahteraan Negara tentu harus diiringi oleh pembangunan hukum baik secara substansi hukum, struktur hukum dan budaya hukum sebagaimana amanat dalam UU RPJP Nasional.

\section{Simpulan}

Konsep daya saing daerah sangat berkorelasi dengan pembangunan hukum, yang mana kedua hal tersebut merupakan program dalam pem- bangunan nasional yang tercantum dalam UU RPJP Nasional dan menjadi arah kebijakan Pemerintah. Selain itu, untuk mewujudkan daya saing yang berkeadilan harus diiringi oleh pembangunan hukum yang memiliki nilai yang hidup di masyarakat. Pembangunan hukum sebagai upaya mewujudkan daya saing daerah maka perlu adanya reformasi pembangunan hukum pada substansi hukum, struktur hukum dan budaya hukum, sehingga hukum dapat dijadikan landasan arah kebijakan dan pelindung untuk meningkatkan daya saing daerah sehingga akan berimplikasi pada kesejahteraan Negara.

\section{Daftar pustaka}

Kusumaatmadja, Mochtar. 1976. Hukum, Masyarakat dan Pembinaan Hukum Nasional Suatu uraian tentang Landasan Pikiran, Pola dan Mekanisme Pembaharuan Hukum di Indonesia. Lembaga Penelitian Hukum dan Kriminologi Fakultas Hukum-Universitas Padjajaran. Bandung. Binacipta.

Mahfud MD, Moh. 1999. Hukum dan Pilar-pilar Demokrasi. Yogyakarta. Gama Media.

Mahfud MD, Moh. 1999. Pergulatan Politik dan Hukum di Indonesia. Yogyakarta. Gama Media.

Manan, Bagir. Dinamika Pembangunan Hukum nasional Berkesinambungan. dalam Eddy Damian. Dinamika Hukum Dalam Pembangunan Berkelanjutan. Fakultas Hukum UNPAD. Bandung. Alumni.

Peraturan Daerah Kota Malang Nomor 5 Tahun 2010 tentang Rencana Pembangunan Jangka Panjang Daerah Tahun 2005-2025. Lembaran Daerah Kota Malang Tahun 2010 Nomor 3 Seri E.

Peraturan Daerah Kota Pontianak Nomor ... Tahun 2014 tentang Rencana Pembangunan Jangka Menengah Daerah Kota Pontianak Tahun 2015-2019.

Prawira, Muhammad Yudha dan Tities Eka Agustine. 2018. Mendorong Daya Saing Ekonomi Daerah dalam Kerangka "Government 3.0". Jurnal CSIS. Centre for Strategic and International Studies. Kuartal Ketiga 2018. Volume 47 Nomor 3.

Setiadi, Wicipto. 2012. Pembangunan Hukum Dalam Rangka Peningkatan Supremasi Hukum. Jurnal Rechtsvinding. Volume 1 Nomor 1. 


\section{Jurnal Cakrawala Hukum, Volume 10 No. 1 Juni 2019}

ISSN PRINT 2356-4962 ISSN ONLINE 2598-6538

Soebagyo, Darsono, Triyono dan Yuli Tri Cahyono. 2013. Regional Competitiveness and Its Implications for Development. Jurnal Ekonomi Pembangunan. Volume 14 Nomor 2.

Undang-undang Nomor 10 Tahun 204 tentang Pembentukan Peraturan Perundang-undangan.
Undang-undang Nomor 17 Tahun 2007 tentang Rencana Pembangunan Jangka Panjang Nasional Tahun 20052025.

Undang-undang Nomor 25 Tahun 2004 tentang Sistem Perencanaan Pembangunan Nasional. 